WSRC-RP-91-1171

$D E 920.40313$

\title{
THE DEPENDENCE OF RADIOLYTIC H2 GENERATION OF THE NITRATE CONCENTRATION IN HIGH-LEVEL SOLUTIONS (U)
} by

D. D. Walker and N. E. Bibler

Westinghouse Savannah River Company

Savannah River Site

Aiken, South Carolina 29808

This report was prepared in connection with work done under Contract No. DE-AC09.89SR 18035 with the U.S. Department of Energy. By acceptance of this report, the publisher and/or recipient acknowledges the U.S. Government's right to retain a nonexclusive, royalty-free license in and to any copyright covering this report, along with the right to reproduce and to authorize others to reproduce all or part of the copyrighted report.

$$
\text { SEP } 021992
$$

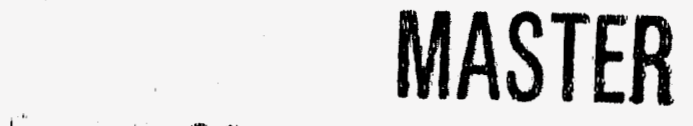




\section{DISCLAIMER}

This report was prepared as an account of work sponsored by an agency of the United States Government. Neither the United States Government nor any agency thereof, nor any of their cmployees, makes any warranty, express or implied, or assumes any legal liability or responsibility for the accuracy, completeness, or usefulness of any information, apparatus, product, or process disclosed, or represents that its use would not infringe privately owned rights. Reference herein to any specific comanercial product, process, or service by trade name, trademark, manufacturer, or otherwise does not necessarily constitute or imply its endorsement, recommendation, or favoring by the United States Government or any agency thereof. The views and opinions of authors expressed herein do not necessarily state or reflect those of the United States Government or any agency therenf.

This report has been reproduced directly from the best available copy.

Available to DOE and DOE contractors from the Oftice of Scientific and Technical Information, P.O. Box 62, Oak Ridge, TN 37831; prices available from (615) 576-8401, FTS 626-8401.

Available to the public from the National Technical Information Service, U.S. Department of Commence, 5285 Port Royal Rd., Springfield, VA 22161. 
Keywords: Tank Farm,

Retention time: permanent

CC: W.A.Tamosaitis, $773-\mathrm{A}$
D.T. Hobbs, $773-\mathrm{A}$
B.I. Lewis, $703-\mathrm{H}$
M.C. Chandler, $703-\mathrm{H}$
P.D.d'Entremont, $703-\mathrm{H}$
M.A. Ceravolo, $703-\mathrm{H}$

November 19,1991

TO: D. I. TISE, 773-A

FROM: D. D. WMIKER and N. Z. BIELRR, 773-A

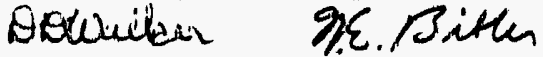

THE DIRENDENCE OF RADIOLYTIC H2 GENHPATION ON THE NITRATE CONCHNYRATION IN HIGE-IEVEI MASTE SOLUTIONS (U)

\section{Summary}

The rate at which hydrogen is produced from the radiolyis of high-activity waste solutions depends on the radiation dose rate to the solution and the concentration of nitrate ion in solution. At a constant dose rate, the hydrogen generation rate decreases as the nitrate ion concentration increases. Using previously measured rates of hydrogen production, an equation has been derived which calculates the hydrogen generation rate when the nitrate ion concentration is known. The hydrogen generation rate from this equation can be used to more accurately predict hydrogen production in waste tanks than is currently obtained assuming a fixed generation rate. The current fixed rate underestimates the hydrogen produced in dilute waste solutions.

\section{Introduction}

During the storage and handling of radioactive waste solutions, hydrogen is generated from the radiolysis of water. Flammable gas mixtures can form in the vapor space above the solutions if the space is not adequately ventilated. Whenever there is a planned or inadvertent ventilation shutdown on a high activity waste tank at the Savannah River Site, an estimate is made of the time required to reach a flammable gas mixture. Currently, these estimates are based on a yield of $6 \mathrm{ft}^{3}$ of hydrogen per million BTU of decay heat 1 and the heat load in the tank. ${ }^{2}$

The generation rate for hydrogen production is dependent on the concentration of nitrate ion in the irradiated solution. 3 As the nitrate ion concentration increases, the rate of hydrogen production decreases. The rate given in the preceding paragraph is that expected from a waste solution containing 1-2 molar nitrate 
ion. This rate is adequate for most tanks containing concentrated waste. However, new processes which are to be run in the Tank Farm, such as Sludge Washing 4 and In-Tank Precipitation, 5 will generate waste solutions with high activities but low nitrate concentrations, Under these conditions, hydrogen accumulation rates in the vapor space in these tanks may exceed estimates made using the hydrogen generation rate given above.

Using previously published results on hydrogen generation by radiolysis, an equation has been derived which gives the rate as a function of the nitrate ion concentration.

\section{Dexivation of Equations}

The rate of $\mathrm{H}_{2}$ production is directly proportional to the radiolytic G-value (moles formed per $100 \mathrm{eV}$ of energy sorbed). Table I lists the G-values for. $\mathrm{H}_{2}$ production, $G\left(\mathrm{H}_{2}\right)$, at different nitrate concentrations. 3,6 The $G$-value is 0.45 molecules $/ 100 \mathrm{eV}$ in distilled water and decreases twenty-fold as the nitrate increases to 8 molar. These data are for both nitric acid solutions and neutral solutions of sodium nitrate. Even though the data are for acid and neutral solutions, the results are expected to be valid for caustic solutions such as the SRS waste. Draganic ${ }^{7}$ has shown that $\mathrm{G}\left(\mathrm{H}_{2}\right)$ is independent of $\mathrm{pH}$ up to a $\mathrm{pH}$ of 13 and hydroxide ion is not expected to significantly effect $G(H 2)$ at higher concentrations.

The equation for the hydrogen generation rate is given in Table II. The equation is applicable in the range $0.003 \mathrm{M}$ nitrate to 8 molar nitrate. Below 0.003 molar, the G-value is the same as that for pure water $(0.45$ molecules/100 eV). 6 A graph comparing the experimental data and the calculated G-values from the equation is shown in Figure 1.

The equation for the rate is given in two different sets of units: moleciles of $\mathrm{H}_{2}$ per $100 \mathrm{eV}$, and $\mathrm{ft}^{3}$ of $\mathrm{H}_{2}$ per milition BTU. As meintioned above, the radiochem'cal literature expresses chemical yields from radiolytic reactions as "G-values" in units of "molecules/100 eV". G-values are directly proportional to generation rates expressed as "ft 3 per milition BTU." The conversion is obtained as follows:

$$
\begin{aligned}
R\left(\frac{f^{3}}{10^{6} \mathrm{BTU}}\right)= & G\left(\frac{\text { molecinles }}{100 \mathrm{eV}}\right) \times \frac{1 \mathrm{eV} / \mathrm{sec}}{1.602 \times 10^{-19} \text { watts }} \times \frac{1054 \text { watt-sec }}{1 \mathrm{BTU}} \times \frac{24.46 \mathrm{I}}{28.32 \mathrm{~L}} \\
& \times \frac{3}{6.022 \times 10^{23} \text { molecules }} \times \frac{3}{100 \mathrm{eV}}
\end{aligned}
$$

The volume of one mole of hydrogen gas $(24.46 \mathrm{~L})$ assumes ideal behavior at $25^{\circ} \mathrm{C}$.

The equation given in Table 1 is not the best fit to the data, but has been modified slightly to produce conservatively high estimates 
of $\mathrm{G}\left(\mathrm{H}_{2}\right)$ over the data range. As can be seen in Fig.1 (solid

line), the equation closely approximates Mahlman's experimental data points. The difference betwer $n$ the calculated G-value and the average of the experimental data is listed in Table $I$. The maximum difference approaches $+40 \%$, but the majority of the data is approximated to within $+20 \%$. Only at 5.0 molar nitrate is Mahlman's experimental measurement higher than that given by the equation and this is probably due to random error in the measurement.

\section{Effect of Other Dissolved Salts}

Nitrate is the mafor anion in soluble waste, but the waste also contains many other species, such as hydroxide, aluminate, sulfate, and nitrite. These other anions and the associated cations have a negligible effect on $\mathrm{G}\left(\mathrm{H}_{2}\right)$ compared to nitrate. This is because nitrate is the only species present that readily reacts with the molecular hydrogen precursors ( $H$ atoms or aqueous electrons)

produced by the radiation. 6 Bradley has irradiated a simulated waste solution containing the major species present in SRS waste. 8 This solution $(4 \mathrm{M} \mathrm{NaNO} 3,2 \mathrm{M} \mathrm{NaNO}, 1 \mathrm{M} \mathrm{NaOH}, 0.6 \mathrm{M} \mathrm{NaAlO} 2,0.5 \mathrm{M}$ $\mathrm{Na}_{2} \mathrm{CO}_{3}$, and $\left.0.3 \mathrm{M} \mathrm{Na}_{2} \mathrm{SO}_{4}\right) 8$ was irradiated at different dose rates and $G$-values for hydrogen were in the range 0.03 to 0.066 molecules/100 eV. The range is similar to Mahlman's data and is consistent with the values calculated from the equation.

\section{Effoct of Alpha Activity}

The G-values used above are based on experiments using co-60 gamma radiation to simulate the effects of a mixture of radionuclides in the waste. Although $\mathrm{CO}-60$ is expected to adequately imitate gamma and beta emitters, 8 it is not a good substitute for alpha emitters. Hydrogen G-values from alpha irradiation are up to three times higher than those from gamma. 9 This effect is not important in estimating hydrogen generation in the soluble waste because the alpha emittors do not contribute significantly to overall radiation energy deposited in the waste. The actinides are highly insoluble in the alkaline waste and contribute less than $0.1 \%$ of the total decay energy. 10 Most of the decay energy is from beta and gamma radiations from $\mathrm{Cs}-137$ and $\mathrm{Ba}-137 \mathrm{~m}$.

In sludge wastes, the alpha contribution is higher and contributes approximately $10 \%$ of the total decay energy. 10 'Thus, the error in ignoring the alpha contribution is similar to the magnitude of the error between the equation and Mahlman's data.

\section{Quality Assurance}

The equations given in Table I were derived using Cricket Graph software (Version 1.2, Feb. 8, 1988, Cricket Software, Malvern, $\mathrm{PA})$ on a Macintosh SE computer. The equations were then evaluated by hand and compared against the experimental data to obtain the errors listed in Table II. This information is recorded in Laboratory Notebook WSRC-NB-91-201, p 51-53, 64-65, 67-68. 


\section{References}

1. Safety Analysis - 200-Area, Liquid Radioactive Waste Handling Facilities, DPSTSA-200-10, SUP 18, August 1988.

2. Heat loads are calculated using the TAFI II code and the results are published periodically. See, for instance, "Waste Management Monthly Data Record, March 1991 (U)," WSRC-RP-91-78-3B, April 18, 1991.

3. H. A. Mahlman, "The OH Yield in the Co-60 Gamma Radiolysis of $\mathrm{HNO}_{3}, "$ J.Chem.Phys., 35, 936 (1961).

4. N. E. Bibler, "Radiolytic $\mathrm{H}_{2}$ Production From DWPF Sludge Feed Solution," DPST-83-373.

5. N. E. Bibler, "Radiolytic $\mathrm{H}_{2}$ Production During the Tank 24 Test of the Precipitation Process," DPST-82-768, August 11, 1982.

6. I. G. Dragaric, and Z. D. Draganic, "The Radiation Chemistry of Water," Academic Press, NY, 1.971.

7. I. G. Draganic, M. T. Nenadovic, and Z. D. Draganic, "Radiolysis of $\mathrm{HCOOH}+\mathrm{O}_{2}$ at $\mathrm{pH} 1.3-13$ and the Yields of Primary Products in Gamma-Radiolysis of Water," J.Fhys.Chem., 73, 2564 (1969).

8. R. F. Bradley, "Radiolysis of Liquid Waste During Bedrock Storage," DP-1264, August 1971.

9. N. E. Bibler, "Curium-244 Alpha Radiolysis of Nitric Acid. Oxygen Production from Direct Radiolysis of Nitrate Ions," J.Fhys.Chem., 78, 211 (1974).

10. R. G. Baxter, "Defense Waste Processing Facility Wasteform and Canister Description," DP-1606 Rev.2, December 1988. 
Table I. Data Used to Derive Equations $\mathrm{G}\left(\mathrm{H}_{2}\right)$ (molecules/100 eV)

Nitrate (molar) Experimental Equation $\frac{\text { Data* }}{\mathrm{HNO} 3}$

0.0012

0.42

0.43

0.47

$+12$

0.0032

0.39

0.41

0.45

$+12$

0.0079

0.39

0.37

0.42

$+1.1$

0.027

0.32

0.36

$+12$

0.031

0.34

0.36

$+6$

0.15

0.24

0.25

0.26

$+8$

0.31

0.19

0.19

0.21

$+11$

0.51

0.15

0.15

0.17

$+13$

0.70

0.12

0.14

$+17$

0.80

0.11

0.13

$+18$

1.0

0.096

0.091

0.118

$+26$

2.0

0.059

0.053

0.071

$+27$

3.0

0.045

0.042

0.049

$+11$

4.0

0.038

0.035

0.037

$+3$

5.0

0.035

0.031 .

$-11$

6.0

0.029

0.020

0.027

$+12$

7.0

0.025

0.025

0

8.0

0.018

0.025

$+39$

* Data taken from Reference 3. Where data is available for both acid and neutral solution, the average of the two has been used to calculate the o difference between the experimental data and the equation. 
TABLE II. Equations for Hydrogen Generation Rates

Range of Nitrate (melar)

$$
0-0.003
$$$$
0.0003-8.0
$$

Equation*

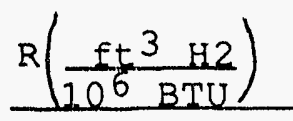

42 .

$$
\begin{aligned}
G= & 50.6 \\
& -61.4\left\{\left[\mathrm{NO}_{3}^{-}\right]^{1 / 3}\right\} \\
& +25.3\left\{\left[\mathrm{NO}_{3}^{-}\right]^{2 / 3}\right\} \\
& -3.32\left\{\left[\mathrm{NO}_{3}{ }^{-}\right]\right\}
\end{aligned}
$$

*The units for $\left[\overline{\mathrm{NO}_{3}}{ }^{-}\right.$] are "molar."

FIGURE 1. Experimental and Calculated G-Values

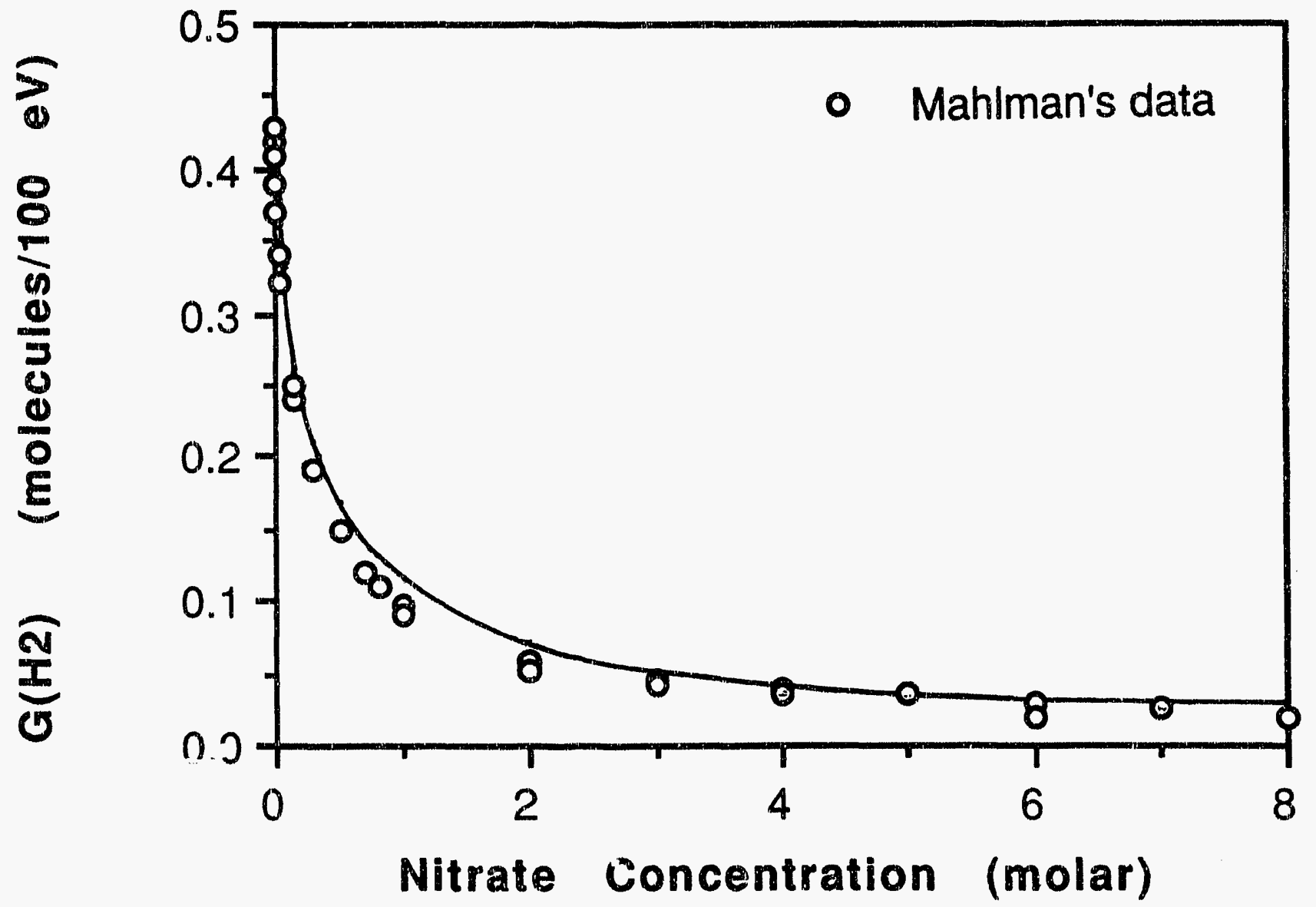



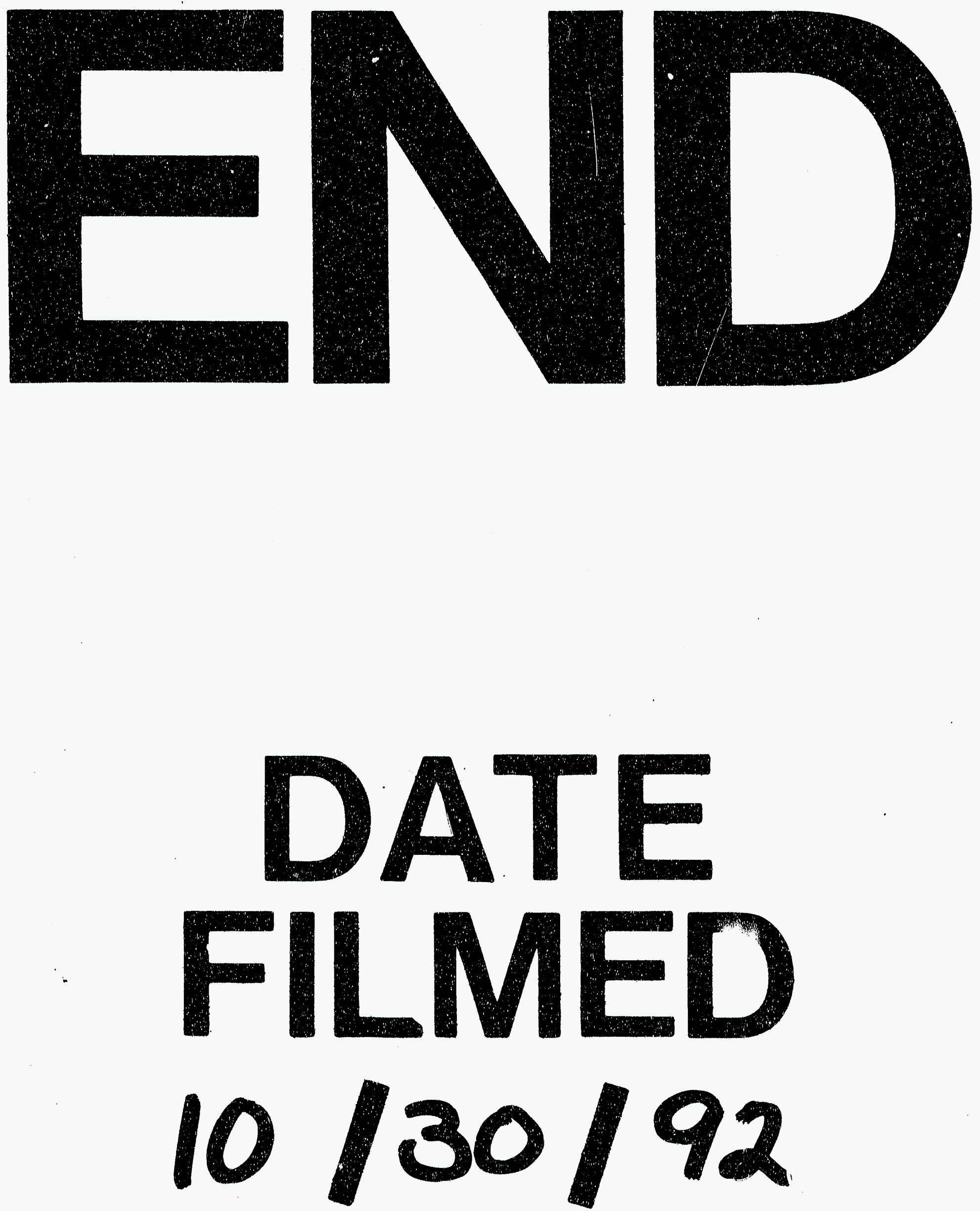
